\title{
The Effect Of Motivation And Leadership Styles Of Lecturer Professions On Organizational Commitment
}

\author{
Ian Nurpatria Suryawan ${ }^{a}$, Ronnie Resdianto Masman ${ }^{b}$, Innocentius Bernarto ${ }^{c}$ \\ ${ }^{a}$ Management Department, Trisakti School of Management \\ ${ }^{b}$ Management Department, Tarumanagara University \\ ${ }^{c}$ Management Department, Pelita Harapan University \\ E-mail:ian.nurpatria@gmail.com
}

\begin{abstract}
This research is intended to test influence Motivation and Leadership Style against Organizational Commitment work lecturer at Universities in Jakarta. The Universities is a private university located in Jakarta, Indonesia. The sample used purposive sampling technique, who works as a lecturer at the Universities. Instrument analysis of data used is multiple regression analysis by the aid Partial Least Square (PLS) program. Based on the results of the study found that there is a positive relationship. The result is Motivation and Leadership Style against Job Satisfaction, Motivation and Leadership Style against Job Performance, Motivation and Leadership Style against Organizational Commitment.
\end{abstract}

Keywords: Motivation, Leadership Style, Lecturer, Job Satisfaction, Performance, Organizational Commitment

\section{BACKGROUND}

In universities, there are always civitas academica consisting of students and lecturers in a university, so Suryawan and Andrew (2013: 55) stated that the main element in shaping the quality of teaching to students is lecturers or faculty other than facilities available in a university. In this case, the private University inJakarta is our choice as a researcher to examine the quality of his teaching and learning. We take a statement from Furqon on the importance of facilities within a University to support the teaching and learning process in order to create high quality for its academic community (Suryawan and Andrew, 2013: 55).

Furthermore, Suryawan and Andrew (2013: 56) attitudes reflecting a professional person can be expressed as a job to be a living source of income that requires expertise, skill, or proficiency and can achieve quality standards for the lecturer profession. Based on the phenomenon, the researchers tried to find out whether the lecturer who has a good job satisfaction is influenced by certain variables, such as motivation influenced by good leadership style, because Diaz-Serrano and Vieira (2005) argue that Job Satisfaction is considered as predictors are important in the welfare of individuals as a whole, so the authors cite the opinion of Martoyo (2000) that to manage human resources it is necessary Job Satisfaction from members of the organization so that will improve Work Performance.

Based on this, the researcher tries to find out whether the relationship between motivation influenced by the leadership style of the leaders in the University from Faculty level to University level can improve job satisfaction which ultimately is expected to improve work performance and organizational commitment from the lecturers at the 
University so that prospective Lecturers or prospective Lecturers from all over Indonesia want to flock to teach at the University in the area of Jakarta.

Research Objectives and Benefits. The purpose of this study is to analyze: Is there a motivation that influenced the leadership style of leaders in universities in the Jakarta area from faculty level to university that can improve job satisfaction of its lecturers, which in turn is expected to increase the commitment to organizations of the lecturers who teaches at the University. While the benefits of this research are: Provide donations of information to the leaders of the University in the area Jakarta from faculty to university level in decision making related to commitment to organization of the lecturers and can be used as a reference and donation of information for researchers in conducting advanced research.

\section{LITERATURE REVIEW}

Motivation. According to Robbins (2001) that motivation belongs to every individual who does the work based on the individual's needs so Winardi (2004) says motivation is a strength that every individual possesses because he has the expectation of getting rewarded to meet his needs as well as his family.

For that, the motivation to look interesting then the leaders of the organization to make motivation in the form of facilities other than wages. Here are the various theories about motivation put forward by management experts: (1) Robbins (2001) says that motivation exists in the theory of hierarchy of needs, ie needs that are divided into levels. First, physical needs, second, security needs, third, social needs, fourth, reward needs, fifth, self-actualization needs; (2) Zurnali (2004) suggests motivational variables consist of: (1) Motives on the needs of the job (Motive); (2) Expectation; (3) The need for reward (Incentive).

Physiological Needs. Feist (2010:331) and Goble (1987:71) states physiological needs are primary needs that every human being has the need to maintain his life physically, ie clothing, food and home. It can be said that humans can not achieve the next need if physiological needs have not been met.

Sense of Security. Furthermore Feist (2010:331) says that security is a matter of physical, stability, dependence, protection and freedom from danger threatening so Feist makes a statement that this need can not be fully fulfilled because everyone can not be protected with certainty from various threats.

Social Needs. Social needs are needs that every human can fulfill after the previous needs have been passed because Goble (1987) states that every human being needs interaction with his peers so that every human being wishes himself to be accepted.

Self-Esteem Needs. Deden (2011) states to the needs after social needs is a need for selfesteem that is feeling, confidence, competence, achievement, mastery, independence and freedom.

Actualization. Deden (2011) states self-actualization is a need to achieve the best or even can be said desire to have will something the best thing. 
Motive. Zurnali (2004) explains that the motive of each individual always has the factors that cause the individual can act for a certain cause in order to achieve the goal of the individual.

Expectations. Suryawan and Andrew (2013) stated that in the hope of every individual always have a decent life because there are guarantees and facilities provided by the leadership of the individuals concerned.

Incentives. Suryawan and Andrew (2013) explain that incentives are the goals of every individual who does the work in accordance with the orders of the leader. In this case, individuals will work according to the vision of the organization.

Leadership Style. The style of leadership is part of a leader in carrying out his leadership and at the time he followed his orders by his followers so that leadership styles are behaviors and strategies as a result of a combination of philosophy, skills, attitudes, attitudes often employed by a leader in influencing the performance of his subordinates (Tampubolon, 2007 ).

Mullins (2005) states leadership style is the style of every individual in leading an organization, then the main activity is to coordinate and guide the efforts of other individuals who fit the vision of the organization. This involves leadership processes and the selection of appropriate actions and behaviors. Leadership style is the main characteristic of organizational performance. Managers must understand the nature of the influence of leadership styles and the factors that determine relationships with subordinates (Mullins, 2005). Kangis and Kelley (2000) also stated that leaders play a role in motivating and harmonizing organizational members to achieve goals.

In this case, Leithwood.et al. (1999) argues that no definitions and concepts of leadership styles are agreed upon, so Subarino (2011:18) finds various definitions and concepts of leadership styles given by leadership experts and researchers and no general definition of leadership style is found.

Influence. Daft (2015) argues that leadership is a relationship that creates an influence between leaders and their followers who share the same vision. Daft (2015) further explains that leadership always involves influences between individuals who desire significant change so that through change it can reflect being intertwined in achieving common goals.

Based on these theories, it can be hypothesized as follows :

$\mathrm{H}_{1}$ : Motivation increases, then Job Satisfaction increases.

$\mathrm{H}_{2}$ : Motivation for Job Satisfaction increases, if Leadership Style increases.

Job Satisfaction. According to As'ad (2012) job satisfaction is the responsibility of each individual that includes cooperation in creating a conducive working situation for the achievement of the vision set by management.

According to Davis (1995: 105) employee job satisfaction to his job is the actualization of employees to the results of his work so Handoko (2000) said job satisfaction is the highest self-actualization of each individual. It can be said that employees who do not get job satisfaction are frustrated, low morale, fatigue and boredom, unstable emotions, busy activities that have nothing to do with work to do and so on. While employees who get job satisfaction perform better than employees who do not get job satisfaction. In this case, researchers argue that job satisfaction is a 
manifestation of self-esteem obtained by each individual after the individual works in accordance with organizational goals. Job satisfaction that will be in the form of Pressure of Work + Social Relations + Self Actualization. The formula is Job Satisfaction $=\mathrm{f}(\mathrm{Job}$ Pressure + Social Relation + Self-Actualization).

Work Performance. According Suharto and Cahyono (2005) work performance is the achievement of the work of each individual based on ability. In this case, Timpe (1992:31) describes the work performance is the work of a person visible from the productivity of his work, so that the productivity of each individual can not be said the same.

Based on these theories, it can be hypothesized as follows :

$\mathrm{H}_{3}$ : Job Satisfaction increases, then Work Performance comes to increase.

Organizational Commitment. Komitmen / ko.mit.men according to Bahasa Indonesia Dictionary (2016) is agreement (attachment) to do something. In this case, according to Sopiah (2008: 155) organizational commitment is the loyalty of employees to the organization where the employee is working so willing to accept all the tasks assigned to him. While Kelley (1999) states every effort of the employees then it can improve the overall productivity of the organization. According to Robbins and Judge (2008: 100) about organizational commitment, which is a state of employees who have the nature of loyalty to an organization and has a goal to maintain membership in the organization.

Based on these theories, it can be hypothesized as follows:

$\mathrm{H}_{4}$ : Work Performance increases, then Organizational Commitment increases.

Previous Research. Preliminary studies that have been done before to support the research to be conducted as contained in the following Table:

Table 1. Previous Research

\begin{tabular}{|c|c|c|}
\hline Research & Title & Results \\
\hline $\begin{array}{l}\text { Kirkpatrick } \\
\text { Lock (1996) }\end{array}$ & - & $\begin{array}{l}\text { More than } 35 \text { studies published in the } \\
\text { journal expressed a positive relationship } \\
\text { between transactional leadership and } \\
\text { subordinate performance }\end{array}$ \\
\hline $\begin{array}{l}\text { Boehnka, } \\
\text { Bontis, }\end{array}$ & & $\begin{array}{l}\text { Different leadership styles have different } \\
\text { effects on business performance }\end{array}$ \\
\hline
\end{tabular}

(2002)

Isnan Masyjui Influence of Motivation and (2005) Work Discipline Against Job Satisfaction Employee Office of National Education Office Grobogan District

Employee motivation in Office of National Education affects job satisfaction of $32.5 \%$, and work discipline has an effect on job satisfaction Employees Office of National Education District Grobogan $26.8 \%$

Luhgiatno (2006)

Roger J. Givens (2008)
Influence Motivation and Ability Performance

Transformational Leadership: The Impact on Organizational and Personal Outcomes
Motivation and Ability influence partially on Performance

Transformational leadership has a positive influence on personal outcomes which demonstrates that transformational leadership has a positive influence on 


\begin{tabular}{ll}
\hline Nurjanah (2008) & $\begin{array}{l}\text { Effect of Leadership Style } \\
\text { and Organizational Culture } \\
\text { on Organizational }\end{array}$ \\
Commitment in Improving \\
Employee Performance \\
(Study On Bureau of Scope \\
of Ministry of Agriculture)
\end{tabular}

Kharisma Perdana Putra (2011)

Jumiati Sasmita The Influence of Ability, (2012)
Analysis of the Effect of Leadership Style on the Achievements of Small and Medium Enterprises (SMEs) in West Sumatra Motivation, and Opportunity to the Working Performance of Pegawai Negeri Sipil (PNS) in Riau Province
Ian - Richard Influence of Motivation to (2013) empowerment, job satisfaction, commitment, trust, self-efficacy beliefs, and motivation.

Leadership style have positive and significant influence to organizational culture, leadership style have positive and significant influence to organizational commitment, organizational culture have positive and significant influence to organizational commitment, organizational commitment have positive and significant impact to employee performance, leadership style have positive and significant influence to employee performance, and culture of the organization have a positive and significant impact on employee performance

Leadership style variable to the achievement of SMEs is equal to $34.5 \%$ rest $65.5 \%$ achievement of SMEs influenced by other factors not revealed in this research

There is a significant influence between the opportunity variables which consist of career development towards employee work motivation in Riau, where ability factor (discipline, education and training and work experience) have strong influence on opportunity (career development), motivation (income, social security, environment work, personality) and job performance (punctuality and quality of work)

The correlation results indicate that there is a positive relationship but tend to be weak between Motivation and Job Satisfaction. It is also known that the variation of Job Satisfaction variables can only be explained by $22.1 \%$ by variation Motivation variables while the other $77.9 \%$ is explained by variations of variables outside Motivation

Motivation of work has a positive and significant influence on the organizational commitment of employees of PT. DAI
Anastasia Tania Effects of Work Motivation dan Eddy $M$. and Job Satisfaction Against Sutanto (2013) Organizational Commitment 
Employees PT.DAI KNIFE KNIFE and job satisfaction have a positive in Surabaya and significant influence on organizational commitment of employees of PT. DAI KNIFE, so it can be said that the motivation of work and job satisfaction together have a positive and significant influence on the organizational commitment of employees of PT. DAI KNIFE

Okto Abrivianto $\mathrm{P}$, Bambang

Swasto,

Hamidah Nayati Utami

(2014)

Winda Kusuma Wardhani, Heru

Susilo,

Mohammad

Iqbal (2015)
Effect of Work Motivation and Commitment to Employee Performance (Study on HRD employees of PT Arthawena Sakti Gemilang Malang)

The Influence of Work Motivation of Employee to Organizational Commitment with Job Satisfaction as Intervening Variable
Work Motivation, Organizational Commitment, has a significant influence on Employee Performance, and Work Motivation is a variable that has a dominant influence on employee performance. Compensation in the form of salary, bonuses and allowances dominant influence terhdap Employee performance

The result of this research shows that hygiene and motivation factors have an effect on organizational commitment through job satisfaction, which can be said that high work motivation can influence the increase of job satisfaction, that is when job satisfaction is high, job satisfaction has indirect effect between satisfaction and organizational commitment

Concept of Research Model. Based on these hypotheses, the influence of Motivation and Leadership Style on Job Satisfaction can be shown by the Concept of Research Model as follows:

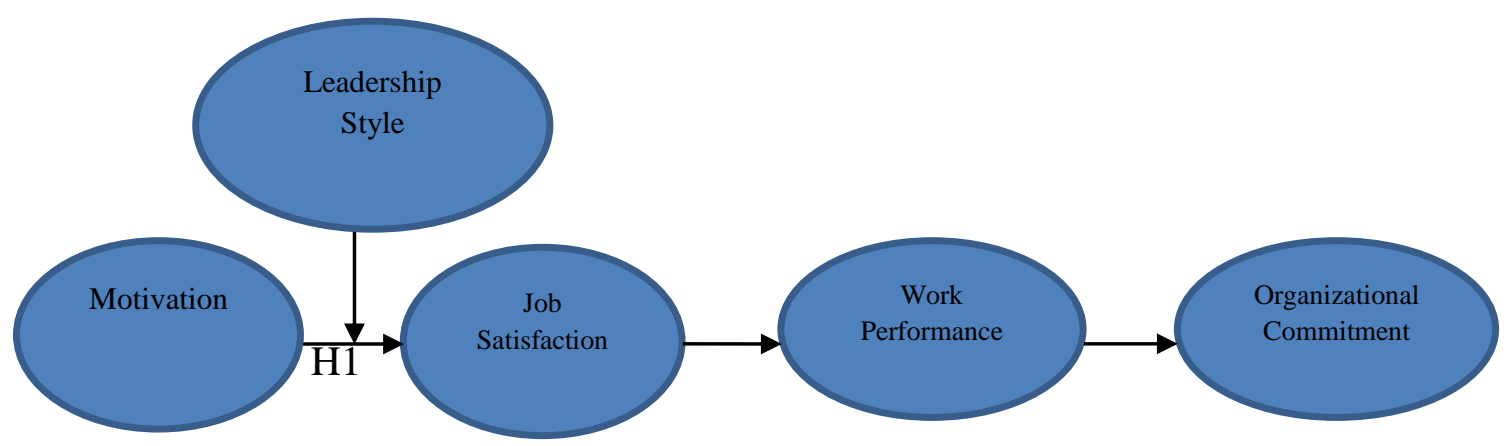

Figure 1. Research Model 


\section{METHOD}

Sampling Method. Sampling by using simple random sampling technique, which specifies subject to be researched by drawing a simple random sample directly from the population (Uma Sekaran, 2000:271). The research design used is Hypothesis Testing Research. The sample studied amounted to 9 indicators x $11=99$ lecturers from the Universities in the area of Jakarta with rounding to 100 lecturers or 100 respondents. Techniques to examine the hypothesis test using Purposive Sampling Technique. To avoid undesirable things like the number of respondents who are less than 100, the Questionaire distributed totals 200 Questionaire.

There are four (4) variables used in this research: Motivation, Leadership Style, Job Satisfaction and Work Performance. Motivation is measured using Abraham Maslow's theory of the hierarchy of needs. There are 5 (five) dimensions: (1) Motives, (2) Hopes and (3) Incentives, and each dimension is measured by a number of statement items. The Leadership Style is measured using 1 dimension: (1) Influence, also each dimension is measured using a number of statement items. While Job Satisfaction is also measured using 3 (three) dimensions:(1) Job pressure, (2) Social relations and (3) Self-actualization and with a number of statement items for each dimension. Work Performance is measured using a number of statement items. Organizational Commitment is measured using a number of statement items.

Variables are measured using five points Likert Scale, where $1=$ Strongly Disagree, $2=$ Disagree, $3=$ Doubtful, $4=$ Agree, and $5=$ Strongly Agree .

To find out whether the instrument used in this study is valid and reliable, then tested the validity and reliability test. Sekaran (2000) states that the Validity test is a test conducted to test whether the statement items used can measure the variables to be measured. Statistically, Validity Test results can be seen that each item statement contained in the questionnaire is valid.

Data Analysis Technique. The analysis technique used in this research is partial least square-structural equation modeling or PLS-SEM. The PLS-SEM analysis consists of two steps : first, outer model and second, inner model. In the outer model, statistical analysis was performed to test the validity and reliability of the instrument. Furthermore, the inner model is testing the hypothesis or testing the relationship between independent variables with the dependent variable. In addition, PLS-SEM can also perform calculations for mediating and moderating variables. In a model that has independent variables, dependent, moderating and mediating can be calculated simultaneously with statistical analysis of PLS-SEM.

In this research, Motivation $\left(\mathrm{X}_{1}\right)$ as independent variable, Leadership Style $\left(\mathrm{X}_{2}\right)$ as moderating variable, Job Satisfaction $\left(\mathrm{Y}_{1}\right)$ and Work Performance $\left(\mathrm{Y}_{2}\right)$ as mediating variable, Organizational Commitment $\left(\mathrm{Y}_{3}\right)$ as dependent variable. The regression equation is as follows:

$$
\begin{aligned}
& \mathrm{Y}_{1}=\mathrm{B}_{1} \mathrm{X}_{1}+\mathrm{B}_{2} \mathrm{X}_{2}+\mathrm{B}_{3} \mathrm{X}_{1} \mathrm{X}_{2}+\mathrm{e}_{1} \\
& \mathrm{Y}_{2}=\mathrm{B}_{4} \mathrm{Y}_{1}+\mathrm{e}_{2} \ldots \ldots \ldots \ldots \ldots \ldots \ldots \ldots \ldots \ldots \ldots \ldots \ldots \ldots \ldots \ldots \ldots \ldots \ldots \ldots \ldots \\
& \mathrm{Y}_{3}=\mathrm{B}_{5} \mathrm{Y}_{2}+\mathrm{e}_{3} \ldots \ldots \ldots \ldots \ldots \ldots
\end{aligned}
$$

Where is: $Y_{1}$ : Job Satisfaction; $Y_{2}$ :Work Performance; $Y_{3}$ :Organizational Commitment; $\mathrm{Bi}$ :The coefficients of the parameters for each variable $\mathrm{X}(\mathrm{i}=1,2,3$ and 4$) ; \mathrm{X}_{1}$ :Motivation; $\mathrm{X}_{2}$ :Leadership Style; $\mathrm{e}_{1}, \mathrm{e}_{2}, \mathrm{e}_{3}$ : error 


\section{RESULTS AND DISCUSSION}

Respondent Profile. Respondents have professions as Lecturers. Aged between 26 - 64 years. Education varies from Magister to Doctorate. Level of Academic Position (JJA) from Asisten Ahli to Guru Besar (Professor) with male and female gender.

Outer Model. Testing the validity and reliability of the instrument is done in the outer model step. Then for validity test is done by calculating outer loading (validity of convergent), Average Variance Extracted (AVE) and discriminant validity. Then the reliability test consists of cronbach alpha and composite reliability.

In this study used composite reliability in accordance with recommendations from Hair et.al. (2014) conditions that must be met for valid instrument is the value of outer loading $>0.7$ and the value of AVE $>0.5$. Furthermore, the discriminant validity must meet the Fornell-Larcker criterion that the quadratic value of AVE or VAVE must be greater than the correlation value between latent variables (Hair et.al, 2014). Then the instrument is reliable if the value of composite reliability is greater than 0.7 (Hair et al, 2014). In table 1 shows the results of validity and reliability tests that have met the requirements.

Table 2.Validityand Reliability Evaluation

\begin{tabular}{lcccc}
\hline \multicolumn{1}{c}{ Variable } & $\begin{array}{c}\text { Indicator } \\
\text { Summary }\end{array}$ & AVE & VAVE & $\begin{array}{c}\text { Composite } \\
\text { Reliability }\end{array}$ \\
\hline Motivation & 9 & 0.668 & 0.817 & 0.948 \\
Leadership Style & 5 & 0.716 & 0.846 & 0.926 \\
Job Satisfaction & 7 & 0.505 & 0.710 & 0.890 \\
Work Performance & 3 & 0.583 & 0.763 & 0.805 \\
Organizational Commitment & 8 & 0.624 & 0.790 & 0.930 \\
\hline
\end{tabular}

Source: Results of Data Processing

Next in Table 2 shows the results of discriminant validity calculations. The result has met the Farnell-Larcker criterion that the AVE quadratic value ( $\sqrt{ } \mathrm{AVE})$ is greater than the correlation value of the variables.

Table 3. Discriminant Validity

\begin{tabular}{|c|c|c|c|c|c|}
\hline & Motivation & $\begin{array}{l}\text { Leadership } \\
\text { Style }\end{array}$ & $\begin{array}{c}\text { Job } \\
\text { Satisfaction }\end{array}$ & $\begin{array}{c}\text { Work } \\
\text { Performance }\end{array}$ & $\begin{array}{l}\text { Organizational } \\
\text { Commitment }\end{array}$ \\
\hline Motivation & 0.817 & & & & \\
\hline $\begin{array}{l}\text { Leadership } \\
\text { Style }\end{array}$ & 0.809 & 0.846 & & & \\
\hline Job Satisfaction & 0.608 & 0.572 & 0.710 & & \\
\hline $\begin{array}{l}\text { Work } \\
\text { Performance }\end{array}$ & 0.419 & 0.470 & 0.544 & 0.763 & \\
\hline $\begin{array}{l}\text { Organizational } \\
\text { Commitment }\end{array}$ & 0.415 & 0.488 & 0.560 & 0.560 & 0.790 \\
\hline
\end{tabular}

Source: Results of Data Processing

From the results seen that Leadership Variables have a response that is equal to 0.846 followed by Motivation Variables of 0.817 , Work Performance of 0.763 and Organizational Commitment of 0.790 and last Variable Job Satisfaction of 0.710. 
Inner Model. The next stage is testing the hypothesis or influence test between variables. Hypothesis testing was performed with attention to a significant level of 5\% and onetailed test. The hypothesis is supported if the value of $\rho$ value is less than the significance level of 0.05 . In table 3 shows that all hypotheses have value $\rho$ value $<0.05$. Thus the decision is all hypotheses supported or significant.

Table 4. Hypothesis Testing

\begin{tabular}{lccc}
\hline \multicolumn{1}{c}{ Hypothesis } & $\begin{array}{c}\text { Standardized Regression } \\
\text { Weight }\end{array}$ & $\rho$ value & Decision \\
\hline $\begin{array}{l}\mathrm{H}_{1}: \text { Motivation increases, then Job } \\
\text { Satisfaction increases }\end{array}$ & 0.444 & 0.002 & Supported \\
$\begin{array}{l}\mathrm{H}_{2}: \text { Motivation for Job } \\
\text { Satisfaction increases, if }\end{array}$ & 0.132 & 0.017 & Supported \\
$\begin{array}{l}\text { Leadership Style increases } \\
\begin{array}{l}\mathrm{H}_{3}: \text { Job Satisfaction increases, } \\
\text { then Work Performance comes to }\end{array}\end{array}$ & 0.544 & 0.000 & Supported \\
$\begin{array}{l}\text { increase } \\
\begin{array}{l}\mathrm{H}_{4}: \text { Work Performance Increases, } \\
\text { then Organizational Commitment } \\
\text { Increases }\end{array}\end{array}$ & 0.560 & 0.000 & Supported \\
\hline
\end{tabular}

Source: Results of Data Processing

So the regression equation becomes:

Job Satisfaction $\quad=0.444$ Motivation +0.239 Leadership Style +0.132
Motivation * Leadership Style +0.586

Work Performance $\quad=\quad 0.544$ Work Performance +0.704

Organizational Commitment $=\quad 0.560$ Work Performance +0.686

The next evaluation is the evaluation of the determinant coefficient or R2. Table 4 shows that Job Satisfaction, Work Performance and Organizational Commitment have R2 values of $0.414,0.296$ and 0.314 , respectively. which means Motivation and Leadership Style greatly affect Job Satisfaction so that Work Performance is increased so that Commitment to Organization becomes high.

Table 5. Evaluation of $\mathrm{R}^{2}$

\begin{tabular}{lc}
\hline \multicolumn{1}{c}{ Variable } & $\mathrm{R}^{2}$ \\
\hline Job Satisfaction & 0.414 \\
Work Performance & 0.296 \\
Organizational Commitment & 0.314 \\
\hline
\end{tabular}

Source: Results of Data Processing

\section{CONCLUSION}

The results showed that Motivation and Leadership Style really affect Job Satisfaction that can improve Work Performance that ultimately can increase the Organizational Commitment of these lecturers. This means that universities in the Jakarta area are obliged to maintain the motivation of every lecturer teaching on campus so that their commitment can continue to increase. With the value of increased Job Satisfaction is 
expected to perform performance and riveting will also be obtained by the lecturers at the universities in the Jakarta area.

Conversely, if the universities does not maintain the motivation of every lecturer to work, this can be indicated to cause a less conducive situation in the teaching and learning process in the classroom. There are several things that can be considered to strengthen the results of research can be held further research on factors that affect Job Satisfaction others because the Motivation and Leadership Style is only able to explain less than a quarter of the Job Satisfaction.

\section{REFERENCES}

As'ad, M. (2012). Psikologi Industri, $4^{\text {th }}$ Edition, Jakarta: Penerbit Liberty

Daft, Richard L. (2015). Leadership, Cengage Learning

Diaz-Serrano, L., Cabral Vieira, J.A., Jose (2005). Low Pay, Higher Pay and Job Satisfactionwithin the European Union: Empirical Evidence from Fourteen Countries, Discussion Papers No. 1558, Institute for the Study ofLabour (IZA)

Feist, Gregory J. (2010). Teori Kepribadian, Salemba Humanika, p.331

G. Goble, Frank (1987). A. Supratiknya, ed. Mazhab Ketiga, Psikologi Humanistik Abraham Maslow, Kanisius, p.71

Hair, Joseph F., Black, William C., Babin, Barry J., Anderson, Rolph E. (2014). Multivariate Data Analysis, $7^{\text {th }}$ Edition, Pearson

Handoko, T. Hani (2000). Manajemen Personalia dan Manajemen Sumber Daya Manusia, BPFE, Yogyakarta

http://berita.upi.edu/2013/01/17/rektor-upi-kualitas-pt-ditentukan-oleh-kultur akademik (accessed on February 20, 2016)

http://ideas.repec.org/p/iza/izadps/dp1558.html(accessed on January 23, 2016)

https://id.wikipedia.org/wiki/Abraham_Maslow (accessed on January 2, 2016)

Isnan Masyjui (2005). "Pengaruh Motivasi dan Disiplin Kerja Terhadap Kepuasan Kerja Pegawai Kantor Dinas Pendidikan Nasional Kabupaten Grobogan”, Skripsi: Fakultas Ilmu Sosial Jurusan Ekonomi, Universitas Negeri Semarang, Semarang

Jumiati Sasmita (2012). "Pengaruh Kemampuan, Motivasi dan Peluang Terhadap Prestasi Kerja Pegawai Negeri Sipil di Provinsi Riau", Media Riset Bisnis \& Manajemen, 12, (1) April, 37-57

Kamus Besar Bahasa Indonesia (KBBI). https://kbbi.web.id/ (accessed on February 12, 2016)

Kangis, P., Kelley, L. L. (2000). "Project Leadership in Clinical Research Organizations”, International Journal of Project Management, 18, 393-401

Keith, Davis, Jhon, W. Newstrom. (1995). Perilaku Dalam Organisasi, Edisi Ketujuh, Jakarta: Erlangga.

Kelley, Robert E., (1999). How to be a Star at Work, New York, Random House.

Leithwood, K. (1994). "Leadership for School Restructuring", Educational Administration Quarterly, 30(4), 498-518

Luhgiatno (2006). "Pengaruh Motivasi dan Kemampuan Terhadap Kinerja”, Jurnal Fokus Ekonomi, STIE Pelita Nusantara, Semarang, 1 (1), Juni 1-12

Martoyo, Susilo (2000). Manajemen Sumber Daya Manusia, BPFE, Yogyakarta

Mullins, J., \& Linehan, M. (2005). The Central Role of Leaders in Public Libraries, Library Management, 26(6), 386-396 
Nurjanah (2008). "Pengaruh Gaya Kepemimpinan dan Budaya Organisasi Terhadap Komitmen Organisasi dalam Meningkatkan Kinerja Karyawan (Studi Pada Biro Lingkup Departemen Pertanian)", Tesis, Program Studi Magister Manajemen, Universitas Diponegoro, Semarang

P., Okto Abrivianto, Swasto, Bambang, Utami, Hamidah Nayati (2014). "Pengaruh Motivasi Kerja dan Komitmen Organisasional Terhadap Kinerja Karyawan (Studi pada karyawan bagian HRD PT. Arthawena Sakti Gemilang Malang)", Jurnal Administrasi Bisnis (JAB), 7 (2) Januari, 1-9

Putra, Kharisma Perdana (2011). "Analisis Pengaruh Gaya Kepemimpinan Terhadap Prestasi Usaha Kecil Menengah (UKM) di Sumatra Barat", Skripsi: Jurusan Manajemen Fakultas Ekonomi, Universitas Andalas, Padang

Rahmat Hidayat, Deden, Zaenudin A. Naufal, (2011). Teori dan Aplikasi Psikologi Kepribadian dalam Konseling, Ghalia Indonesia, pp. 165-166

Reza, Regina Aditya (2010). "Pengaruh Gaya Kepemimpinan, Motivasi dan Disiplin Kerja Terhadap Kinerja Karyawan PT. Sinar Sentosa Perkasa Banjarnegara", Skripsi: Fakultas Ekonomi Universitas Diponegoro

Robbins, Stephen P. Judge, Timothy A. (2008). Perilaku Organisasi: Organizational Behaviour, Edisi 12, Dialihbahasakan Oleh Diana Angelica, Ria Cahyani, dan Abdul Rosyid, Jakarta: Salemba Empat

Robbins, Stephen, P. (2001). Teori Organisasi, Struktur, Desain dan Aplikasi, Edisi ke 5,Penerbit Arcan, Jakarta

Roger J. Givens (2008). "Transformational Leadership: The Impact on Organizational and Personal Outcomes”, Emerging Leadership Journeys: School of Global Leadership and Entrepreneurship, Regent University, 1 (1), 2008, 4-24

Sanusi, Anwar (2011). Metodologi Penelitian Bisnis, Jakarta: Penerbit Salemba Empat.

Sekaran, U. (2006). Metode Penelitian Untuk Bisnis, Edisi ke 4, Jakarta: Penerbit Salemba Empat.

Sopiah (2008). Perilaku Organisasional, Penerbit Andi, Malang

Subarino, Alib, A.J., Tang Keow Ngang, T.K. (2011). "Kepemimpinan Integratif: Sebuah kajian Teori", Jurnal Manajemen Pendidikan, 01 (VII),17-50

Suharto, Budhi Cahyono (2005). "Pengaruh Budaya Organisasi, Kepemimpinan dan Motivasi Kerja Terhadap Kinerja Sumber Daya Manusia di Sekretariat DPRD Propinsi Jawa Tengah", JRBI, 1 (1), 13-30

Suryawan, Ian Nurpatria, Andrew, Richard (2013). "Pengaruh Motivasi Terhadap Kepuasan Kerja”, Jurnal Media Riset Bisnis dan Manajemen, 13 (1), 54-61, Fakultas Ekonomi Universitas Trisakti, Jakarta.

Tampubolon, Biatna. D. (2007). "Analisis Faktor Gaya Kepemimpinan dan Faktor Etos Kerja Terhadap Kinerja Pegawai Pada Organisasi Yang Telah Menerapkan SNI 199001-2001”, Jurnal Standardisasi, 9,106-115

Tania, Anastasia, Sutanto, Eddy M. (2013). "Pengaruh Motivasi Kerja dan Kepuasan Kerja Terhadap Komitmen Organisasional Karyawan PT. DAI Knife di Surabaya”, Jurnal AGORA, 1 (3)

Terry, G.R.,W. Rue, Leslie (2008). Dasar-Dasar Manajemen, Jakarta: Bumi Aksara

Thoha, Miftah (2013). Perilaku Organisasi Konsep Dasar dan Aplikasinya, PT Raja Grafindo Persada, Jakarta

Timpe, Dale (1992). Seri Ilmu dan Seni Manajemen Bisnis, PT. Elex Media Komputindo, Jakarta 
Wardhani, Winda Kusuma, Susilo, Heru, Iqbal, Mohammad (2015). "Pengaruh Motivasi

Kerja Karyawan Terhadap Komitmen Organisasional Dengan Kepuasan Kerja

Sebagai Variabel Intervening", Jurnal Administrasi Bisnis (JAB), 2 (1),1-10

Winardi, J. (2004). Motivasi dan Pemotivasian Manajemen, Jakarta: Penerbit PT. Raja Grafindo Persada.

Zurnali, Cut (2004). "Pengaruh Pelatihan dan Motivasi Terhadap Perilaku Produktif Karyawan Divisi Long Distance PT Telkom Tbk", Tesis , Unpad, Bandung 